\title{
Conditions associated with sarcopenia and sarcopenic obesity among community- dwelling older people
}

Condições associadas à sarcopenia e obesidade sarcopênica entre idosos residentes na comunidadle Condiciones asociadas con sarcopenia y obesidad sarcopénica en personas mayores independientes

Rita de Cássia da Silva Almeida Lira ORCID: https://orcid.org/0000-0001-7587-304X University of Pernambuco, Brazil E-mail: rita.lira@upe.br

Amanda Carla Corrêa Viana ORCID: https://orcid.org/0000-0002-4442-7140 University of Pernambuco, Brazil E-mail: amanda.correa@upe.br

Adrielle Cavalcanti de Pontes Araújo ORCID: https://orcid.org/0000-0002-7197-0309 University of Pernambuco, Brazil

E-mail: adrielle_pontes@hotmail.com Ulisses Tirollo Taddei ORCID: https://orcid.org/0000-0002-8104-1415 University of São Paulo, Brazil E-mail: utaddei@gmail.com

Ana Célia Oliveira dos Santos ORCID: https://orcid.org/0000-0002-9170-5684 University of Pernambuco, Brazil E-mail: ana.oliveira@upe.br

\begin{abstract}
Objective: to investigate the factors associated with sarcopenia and sarcopenic obesity (SO) in community-dwelling older people. Methods: This was a cross-sectional community-based study. Sarcopenia was diagnosed according to the cutoff points of hand grip strength (HGS), and SO was identified through a low HGS concomitant with a high body fat percentage, according to sex, determined using electrical bioimpedance. Calorie and protein intake was estimated using a 24-hour recall. Socio-demographic data were obtained by means of an interview and the level of physical activity was assessed using a specific instrument. Results: Prevalence of $43 \%$ and $19.6 \%$ were observed for sarcopenia and SO, respectively. Older people aged $\geq 70$ years have a significantly higher risk for sarcopenia in $183 \%(\mathrm{PR}=2.83 ; 95 \% \mathrm{CI}$ $=$ [1.62 to 4.96]; $\mathrm{p}$ value < 0.001) compared to those aged 60 to 69 years. The prevalence of sarcopenia was higher in males, among those who contribute to family support, present comorbidities and are less physically active. The prevalence of SO and sarcopenia was high, but this study did not allow us to observe statistically significant associations. Calorie and protein intakes were predominantly inadequate throughout the sample, however, there was no association with sarcopenia and SO. Conclusion: Advance years of life was shown to be a factor associated with sarcopenia, and with SO. Contributing to family support and insufficient physical activity were determining conditions for the occurrence of sarcopenia.
\end{abstract}

Keywords: Aging; Muscle mass; Physical activity.

\section{Resumo}

Objetivo: investigar os fatores associados à sarcopenia e obesidade sarcopênica (OS) em idosos residentes na comunidade. Métodos: estudo transversal de base comunitária. A sarcopenia foi diagnosticada de acordo com os pontos de corte da força de preensão palmar (FPP), e a OS foi identificada através de baixa FPP concomitante a uma alta porcentagem de gordura corporal, de acordo com o sexo, utilizando a bioimpedância elétrica. A ingestão de calorias e proteínas foram estimadas utilizando um recordatório de 24 horas. Os dados sócio-demográficos foram obtidos através de uma entrevista e o nível de atividade física foi avaliado utilizando um instrumento específico. Resultados: foi observada uma prevalência de $43 \%$ e $19,6 \%$ para a sarcopenia e OS, respectivamente. Idosos com $\geq 70$ anos têm um risco significativamente mais elevado de sarcopenia em $183 \%(\mathrm{RP}=2,83 ; 95 \% \mathrm{IC}=[1,62$ a 4,96]; valor de $\mathrm{p}<0,001)$ em comparação com os de 60 a 69 anos. A prevalência de sarcopenia foi maior em homens, entre aqueles que contribuem para o sustento familiar, apresentam comorbidades e são menos ativos fisicamente. A prevalência de OS e sarcopenia foi alta, mas este estudo não nos permitiu observar associações estatisticamente significativas. A ingestão de calorias e proteínas foram inadequadas em todas as amostras, contudo, não houve associação com a sarcopenia e o OS. Conclusão: 
a idade avançada mostrou ser um fator associado à sarcopenia e a OS. Contribuir com o suporte familiar e a atividade física insuficiente foram determinantes para a sarcopenia.

Palavras-chave: Envelhecimento; Massa muscular; Atividade física.

\section{Resumen}

Objetivo: investigar los factores asociados a sarcopenia y Obesidad Sarcopénica (OS) en personas mayores independientes. Métodos: estudio transversal basado en la comunidad. La sarcopenia se diagnosticó según los puntos de corte de la Fuerza de Prensión Manual (FPM), y la OS se identificó a través de una baja FPM y un alto porcentaje de grasa corporal, según el sexo, se ha determinado mediante bioimpedancia eléctrica. La ingesta de calorías y proteínas se estimó mediante un cuestionario. Los datos sociodemográficos se obtuvieron por una entrevista la actividad física se evaluó mediante un instrumento específico. Resultado: una prevalencia del 43\% y del 19,6\% para la sarcopenia y la OS, respectivamente. Las personas mayores de 70 años tienen un riesgo significativamente mayor de sufrir sarcopenia en un 183\% (PR = 2,83; IC del 95\% = [1,62 a 4,96]; valor de p < 0,001) en comparación con las de 60 a 69 años. La prevalencia de sarcopenia fue mayor en los varones, ya que presentan comorbilidades y son menos activos físicamente. La prevalencia de la OS fue mayor en las mismas condiciones que la sarcopenia, en este estudio no permitió observar asociaciones significativas. La ingesta de calorías y proteínas fue inadecuada en toda la muestra, sin embargo, no hubo asociación con la sarcopenia y el OS. Conclusión: Los años de vida avanzada se mostraron como un factor asociado a la sarcopenia, y a la OS. El apoyo familiar y la insuficiente actividad física fueron condiciones determinantes para la aparición de la sarcopenia.

Palabras clave: Envejecimiento; Masa muscular; Actividad física.

\section{Introduction}

Sarcopenia is defined as a progressive loss of muscle mass and strength (Dent et al., 2018; Choi, 2016; Janssen, 2011). However, there is no consensus on diagnosis and the most commonly used criterion for defining sarcopenia is the European Working Group on Sarcopenia in Older People (EWGSOP) (Cruz-Jentoft et al., 2010). Sarcopenic obesity (SO) is a clinical condition determined by sarcopenia concomitant with obesity, and is assessed through the percentage body fat (\%BF) (Baumgartner et al., 2004).

The worldwide prevalence of sarcopenia has been estimated at around 50 million cases and progressions, indicating that within the next 40 years this number could rise to 200 million (Chung, Kang, Lee, Lee, \& Le, 2013). In community-dwelling older people, the prevalence of sarcopenia ranges from $1 \%$ to $29 \%$ (Cruz-Jentoft et al., 2014).

Changes in body composition in older people are associated with a sedentary lifestyle, poor eating habits, insulin resistance and muscle fatty infiltration. These conditions influence muscle inflammation, concomitant with the natural aging process, which results in a loss of muscle mass and function, thus impairing the physical performance of older people (Morley et al., 2011; Zhang et al., 2019). The double metabolic burden of obesity and sarcopenia potentiates unfavorable health outcomes for older people, such as frailty, chronic non-communicable, metabolic, and cardiovascular diseases, a lower quality of life and higher morbidity and mortality rates (Tian \& Xu, 2016; Lombardo et al., 2019; Waters, Hale, Grant, Herbison, \& Goulding, 2010).

Although many factors may contribute to the development of these conditions, it has been argued that age, gender, family support, inadequate food consumption and a sedentary lifestyle are among the most consistent factors for the risk of developing sarcopenia and obesity (Cross -Jentoft et al., 2010; Mithal et al., 2013). Some studies suggest that strength training and adequate amounts of energy and protein intake are important for reducing the progression of related muscle mass and strength loss (Houston et al., 2008; Beasley, Shikany, \&Thomson, 2013).

It is important to identify factors associated with these clinical conditions, since they are two pathologies with a negative impact on the quality of life and risk of mortality, becoming a public health problem with high costs for the health system (Confortin, Ono, Barbosa, \& d'Orsi, 2018). This study has aimed to investigate the occurrence and factors associated with sarcopenia and SO in community-dwelling older people. 


\section{Methodology}

This was a cross-sectional community-based study. Older people attending the Universidade Aberta à Terceira Idade [Open University for Older People] (UnATI) in Recife-PE, Brazil were included. The research was approved by the Research Ethics Committees CAAE: 17029319.1.0000.5192 and CAAE: 17029319.1.3001.5208.2019. All participants were informed about the study objectives and signed the informed consent forms.

Individuals of both sexes, aged 60 years or over, enrolled on the UnATI and with a score greater than or equal to 20 in the Mini Mental State Examination (Folstein et al., 1975) participated in the study. Individuals with mobility difficulties, using pacemakers or impaired cognition were excluded.

Personal identification, sociodemographic, economic and clinical data were collected by applying a questionnaire, through an interview.

\subsection{Diagnosis for Sarcopenia and Sarcopenic Obesity (SO)}

Sarcopenia was diagnosed according to the EWGSOP cutoff points, using hand grip strength (HGS). The results of muscle mass and gait speed tests were also analyzed as independent variables (Cruz-Jentoft et al., 2010). The association of a low HGS together with a high \%BF, established according to gender, was classified as SO.

\subsubsection{Muscle strength}

Muscle strength was obtained with the HGS, measured with a Saehan®, SH 5001 hydraulic dynamometer. The tests were performed in triplicate, in the dominant hand, through verbal commands by the examiner. The older people were instructed to grip the dynamometer for six seconds and then relax. The mean value of the results was then calculated. A reduction in muscle strength, dynapenia, was recorded per kilogram/force (kg/f), for which levels below $30 \mathrm{~kg} / \mathrm{f}$ for males and below $20 \mathrm{~kg} / \mathrm{f}$ for females were considered (Cruz-Jentoft et al., 2010).

\subsubsection{Muscle mass}

Muscle mass was assessed by tetrapolar bioelectrical impedance analysis (BIA), with a portable Sanny® BIA 1010 device that applies a current of 500 to $800 \mu \mathrm{A}$. The technique and procedures were performed according to Kyle et al., (2004). The recommendations such as to avoid water and food consumption for 4 hours and to exercise for 24 hours before BIA assessment were previously done (Kyle et al.,2004). The appendicular skeletal muscle mass index (ASMMI) was used, through the equation: ASMMI $=$ ASMM/Height ${ }^{2}$, where the ASMM $=$ appendicular skeletal muscle mass adjusted for height squared. The ASMM, in turn, was calculated according to the formula by Janssen et al., (2000): ASMM $(\mathrm{kg})=[($ height $2 /$ resistance $) \times$ $0.401]+($ gender $\times 3.825)+($ age $\times-0.071)+5.102$ where height is measured in centimeters $\left(\mathrm{cm}^{2}\right)$; weight in kilograms $(\mathrm{Kg}), \mathrm{R}$ $=$ Resistance in ohms; female sex $=0$ and male $=1$ and age in years. A cutoff point for low muscle mass was defined as an ASMM $<8.87 \mathrm{~kg} / \mathrm{m}^{2}$ for males and $<6.42 \mathrm{~kg} / \mathrm{m}^{2}$ for females (Janssen, Heymsfield, Baumgartner, \& Ross, 2000).

\subsubsection{Gait speed (GS)}

To assess the GS, the older people were instructed to walk for $4.0 \mathrm{~m}$ at their usual speed on a straight, flat surface, timing how long it took to cover this distance. A slow gait was considered when the speed was $\leq 0.8 \mathrm{~m} / \mathrm{s}$. This criterion was considered for the definition of severe sarcopenia, when a reduction in muscle mass and strength was observed to be associated with a low gait speed (Cruz-Jentoft et al., 2010). 


\subsubsection{Obesity}

Obesity was assessed through the percentage of total body fat using the BIA, considering a percentage of $\geq 28 \%$ for males and $\geq 40 \%$ for females (Baumgartner et al., 2004).

\subsection{Physical activity}

The level of physical activity was measured using a questionnaire by Rauchbach and Wendling, (2009). This is an instrument composed of questions related to the frequency and time spent with activities performed by the older people during the previous week, regarding systematic practices of physical activity, domestic activities or heavy work and social activities or leisure. Those assessed were classified as slightly active ( $\leq 82$ points) and active ( $\geq 83$ points).

\subsection{Dietary intake}

Dietary intake was assessed through two 24-hour dietary recalls (24HR), with the aim of determining the intrapersonal variation of food intake of the individuals studied, proposed by the Iowa State University (Guenther, Kott, \& Carriquiry, 1997; Carriquiry,1999). Dietary intake was obtained by homemade measures and then converted into grams in order to quantify calories and proteins. The nutritional composition of the diet was analyzed with the aid of the nutritional software WebDiet. The mean calorie and protein dietary intake was obtained together with the adequacy of the prevalence according to the values of the Dietary Reference Intakes (DRIs) established by The Institute of Medicine (Trumbo, Schlicker, Yates, \& Poos, 2002). The estimated total energy value (TEV) considered adequate for the study was an intake $\geq 1500 \mathrm{kcal}$ and $\geq 77 \mathrm{~g}$ of protein. Intake below the established levels was considered inadequate.

\subsection{Statistical analysis}

A database was constructed for the data analysis on a Microsoft Excel@ 2013 spreadsheet, which was exported to RCore Team 2018 4.0.3, where the analysis was performed. The socioeconomic and clinical profiles and life habits of the older people were assessed and the percentage frequencies and frequency distributions were calculated. To assess which factors were associated with sarcopenia and sarcopenic obesity, contingency tables were constructed and the Chi-square test of independence was applied. In cases where the suppositions of the Chi-square test were unsatisfactory, the Fisher's exact test was applied. In the assessment of the ASMM and GS, the mean values and standard deviations were calculated. The comparisons of the mean values of the ASMM and the GS between those with sarcopenia and those without sarcopenia, and between those with sarcopenic obesity and those without sarcopenic obesity were performed with the Student T-test for independent samples. All conclusions of the analysis were taken considering a significance level of $5 \%$.

In the multivariate analysis, the variables that presented a statistical significance of up to $20 \%(p=0.20)$ were included in the bivariate analysis. The Poisson model was applied with a robust variance for assessing the determining factors in sarcopenia. For the permanence of the factors in the logistical model, a significance level of 5\% was considered. Confidence intervals (CI) were calculated for the prevalence ratio and the Wald's test was used to compare the risks for sarcopenia and the ROC curve was estimated to determine the adjusted power of the model.

The normal distribution of all the continuous variables was confirmed using the Kolmogorov-Smirnov test for adhesion. The Pearson correlation test was used for these continuous variables seeking linear associations between the variables in sarcopenia. 


\section{Results}

A total of 51 older people participated in the study. The prevalence of sarcopenia, by predicting a low HGS, was 43\%, and when a combination of the ASMMI and a low HGS was 21.56\%, and a low HGS associated with a low ASMMI with the GS, the prevalence was $1.96 \%$, the latter association being classified as severely sarcopenic. The prevalence of SO in the sample was $19.60 \%$.

The distribution of the classification of sarcopenia and SO (Table 1), according to the profile of the assessed participants, presented a higher prevalence in the males, half of whom presented with sarcopenia, were aged 70 years or over $(65,0 \%)$, did not live alone (44.4\%), contributed to family support (54.8\%), presented comorbidities (46.2\%), with more than three comorbidities (80\%) and engaged in insufficient physical activity (50.0\%). The independence test for this analyzed group was significant: age ( $\mathrm{p}=0.011)$, contributed to family support $(\mathrm{p}=0.036)$ and insufficient physical active $(\mathrm{p}=0.088)$.

For SO, there was a higher prevalence in older males (33.3\%), aged 70 years or over (25\%), did not live alone (22.2\%), contributed to family support (25.8\%), presented comorbidities (23\%), with more than three comorbidities (40\%) and engaged in insufficient physical activity (20\%). However, the independence test was not significant for the assessed factors. 
Table 1. General characteristics of sarcopenia and SO classification according to sociodemographic data, clinical and economic profiles and physical activity of community-dwelling older people.

\begin{tabular}{|c|c|c|c|c|c|c|c|c|}
\hline \multirow[b]{2}{*}{ Features } & \multirow[b]{2}{*}{$\mathbf{n}$} & \multirow[b]{2}{*}{$\%$} & \multicolumn{2}{|c|}{ Sarcopenia } & \multicolumn{4}{|c|}{ SO } \\
\hline & & & $\begin{array}{r}\text { Yes } \\
\text { n (\%) }\end{array}$ & $\begin{array}{r}\text { No } \\
\text { n (\%) }\end{array}$ & p-value & $\begin{array}{c}\text { Yes } \\
\text { n }(\%)\end{array}$ & $\begin{array}{c}\text { No } \\
\text { n (\%) }\end{array}$ & p-value \\
\hline \multicolumn{9}{|l|}{ Sex } \\
\hline Male & 6 & 12 & $3(50.0)$ & $3(50.0)$ & \multirow{2}{*}{$1.000^{2}$} & $2(33.3)$ & $4(66.7)$ & \multirow{2}{*}{$0.583^{2}$} \\
\hline Female & 45 & 88 & $19(42.2)$ & $26(57.8)$ & & $8(7.8)$ & $37(82.2)$ & \\
\hline \multicolumn{9}{|l|}{ Age } \\
\hline \multirow[t]{2}{*}{ 60-69 years old } & 31 & 61 & $9(29.0)$ & $22(71.0)$ & \multirow{3}{*}{$0.011^{1}$} & $5(16.1)$ & $26(83.9)$ & \multirow{3}{*}{$0.486^{2}$} \\
\hline & & & & & & & & \\
\hline$\geq 70$ years old & 20 & 39 & $13(65.0)$ & $7(35.0)$ & & $5(25)$ & $15(75)$ & \\
\hline \multicolumn{9}{|l|}{$\begin{array}{l}\text { Family } \\
\text { Arrangement }\end{array}$} \\
\hline Living alone & 15 & 29 & $6(40.0)$ & $9(60.0)$ & \multirow{2}{*}{$0.770^{1}$} & $2(13.3)$ & $13(86.7)$ & \multirow{2}{*}{$0.702^{2}$} \\
\hline Not living alone & 36 & 71 & $16(44.4)$ & $20(55.6)$ & & $8(22.2)$ & $28(77.8)$ & \\
\hline \multicolumn{9}{|l|}{$\begin{array}{l}\text { Family } \\
\text { Breadwinner }\end{array}$} \\
\hline Yes & 31 & 61 & $17(54.8)$ & $14(45.2)$ & \multirow{2}{*}{$0.036^{1}$} & $8(25.8)$ & $23(74.2)$ & \multirow{2}{*}{$0.280^{2}$} \\
\hline $\begin{array}{l}\text { No } \\
\text { Comorbidity }\end{array}$ & 20 & 39 & $5(25.8)$ & $15(75.0)$ & & $2(10)$ & $18(90)$ & \\
\hline Yes & 39 & 77 & $18(4.2)$ & $21(53.8)$ & \multirow{2}{*}{$0.433^{1}$} & $9(23)$ & $30(77)$ & \multirow{2}{*}{$0.417^{2}$} \\
\hline No & 12 & 24 & $4(33.3)$ & $8(66.7)$ & & $1(9)$ & $10(91)$ & \\
\hline \multicolumn{9}{|l|}{$\begin{array}{l}\text { Number of } \\
\text { comorbidities }\end{array}$} \\
\hline 0 & 12 & 24 & $4(33.3)$ & $8(66.7)$ & & $1(8.3)$ & 11(91.7) & \\
\hline 1 & 13 & 26 & $5(38.5)$ & $8(61.5)$ & & $3(23.0)$ & $10(77.0)$ & \\
\hline 2 a 3 & 21 & 41 & $9(42.9)$ & $12(57.1)$ & $0.398^{2}$ & $4(19.0)$ & 17(81.0) & $0.398^{2}$ \\
\hline$>3$ & 5 & 10 & $4(80.0)$ & $1(20.0)$ & & $2(40.0)$ & $3(60.0)$ & \\
\hline
\end{tabular}

Physical Activity

\begin{tabular}{lccccccc} 
Slightly active & 40 & 78 & $20(50.0)$ & $20(50.0)$ & & $8(20.0)$ & $32(80.0)$ \\
& & & & & $0.088^{2}$ & & $1,000^{2}$ \\
Active & 11 & 22 & $2(18.2)$ & $9(81.8)$ & & $2(18.2)$ & $9(81.8)$ \\
\hline
\end{tabular}

\footnotetext{
${ }^{1}$ p-value: Chi- squared test. ${ }^{2} \mathrm{p}$-value Fisher's exact test. Source: Own Research.
}

According to the classification for sarcopenia, it was demonstrated that the group with sarcopenia presented a lower mean ASMMI than the group without sarcopenia (Table 2). For the GS, the groups with and without sarcopenia presented similar mean values. Although a difference was observed between the groups in the mean value of the ASMMI and the GS, the mean 
comparison test was not significant for the assessed factors, indicating that there was no relevant difference in the ASMMI and the GS between the groups, considering the number of participants of this research.

The group of older people with SO (Table 2) presented a lower mean ASMMI than the group without SO, and for the GS, the SO group presented a higher mean value than the group without SO. Although a difference was observed between the groups in the mean value of the ASMMI and the GS, the mean comparison test was not significant for the factors assessed.

Table 2. Mean and standard deviation of body composition (ASMMI) and GS according to the sarcopenia and SO classification.

\begin{tabular}{|c|c|c|c|}
\hline \multicolumn{4}{|c|}{ Sarcopenia } \\
\hline Feature & Yes & No & p-value ${ }^{1}$ \\
\hline ASMMI & $6.83 \pm 1.28$ & $7.09 \pm 1.27$ & 0.487 \\
\hline GS & $3.97 \pm 1.09$ & $3.73 \pm 0.78$ & 0.383 \\
\hline \multicolumn{4}{|c|}{ SO } \\
\hline Feature & Yes & No & p-value ${ }^{1}$ \\
\hline ASMMI & $6.66 \pm 1.13$ & $7.05 \pm 1.29$ & 0.358 \\
\hline GS & $4.10 \pm 1.03$ & $3.76 \pm 0.89$ & 0.36 \\
\hline
\end{tabular}

${ }^{1}$ p-value Student's t-test to compare means ASMMI: Appendicular Skeletal Muscle Mass Index GS: Gait Speed Source: Own Research.

The distribution of food calorie intake was inadequate in $43.3 \%$ of the population studied and the protein intake was adequate among only $47.8 \%$ of those with sarcopenia (Table 3). Although a higher prevalence of sarcopenia was observed in the group of older people with the described profile, the independence test was not significant. The calorie intake of those with OS was adequate in $23.8 \%$, and protein intake was considered inadequate in $21.4 \%$. Although a higher prevalence of inadequacy was found in the group of elderly people with the described profile, there was no significant p-value, it is inferred that the variables were not predictive or the model has low power, probably due to the low number of individuals with SO.

The caloric intake by those with SO was adequate in $23.8 \%$, and protein intake was considered inadequate in $21.4 \%$. Although a higher prevalence of inadequacy was observed in the group of older people with the described profile, there was no significant p-value, and it may be inferred that the variables are not predictive or the model has low power, probably due to the low number of individuals with OS.

Table 3. Distribution of calorie and protein intake of sarcopenic and SO in older people.

\begin{tabular}{|c|c|c|c|c|c|c|c|c|}
\hline & & & Sarcopeni & & & SO & & \\
\hline Features & $\mathbf{n}$ & $\%$ & $\begin{array}{l}\text { Yes } \\
\text { n (\%) }\end{array}$ & $\begin{array}{l}\text { No } \\
\text { n }(\%)\end{array}$ & p-value ${ }^{1}$ & $\begin{array}{l}\text { Yes } \\
\text { n (\%) }\end{array}$ & $\begin{array}{l}\text { No } \\
\text { n }(\%)\end{array}$ & p-value ${ }^{2}$ \\
\hline \multicolumn{9}{|l|}{ Calorie intake } \\
\hline Inadequate & 30 & 59 & $13(43.3)$ & $17(56.7)$ & \multirow{3}{*}{0.97} & $5(16.7)$ & $25(83.3)$ & \multirow{3}{*}{0.72} \\
\hline Adequate & 21 & 41 & $9(42.9)$ & $12(57.1)$ & & $5(23.8)$ & $16(76.2)$ & \\
\hline Protein intake & & & & & & & & \\
\hline Inadequate & 28 & 55 & $11(39.3)$ & $17(60.7)$ & \multirow{2}{*}{0.54} & $6(21.4)$ & $22(77.8)$ & \multirow{2}{*}{1.00} \\
\hline Adequate & 23 & 45 & $11(47.8)$ & $12(52.2)$ & & $4(17.4)$ & $19(82.6)$ & \\
\hline
\end{tabular}

${ }^{1}$ p-value: Chi-squared test.

${ }^{2}$ p-value Fisher's exact test.

Source: Own Research 
The final adjustment of the Poisson model for sarcopenia demonstrated that those in the aged 70 years and over presented a significantly higher risk for sarcopenia of $183 \%(\mathrm{PR}=2.83 ; 95 \% \mathrm{CI}=[1.62$ to 4.96$]$; $\mathrm{p}$ value <0.001) when compared with the group of individuals aged 60 to 69 years. The group of older people who contributed to family support presented a significantly higher risk for sarcopenia of $187 \%(\mathrm{PR}=2.87 ; 95 \% \mathrm{CI}=[1.35$ to 6.09$]$; $\mathrm{p}$-value $=0.005)$ when compared to the group of older people who did not help to support the family (Table 4).

Table 4. Final adjustment of the Poisson regression model for sarcopenia.

\begin{tabular}{llll}
\hline Feature & PR & CI 95\% & p-value $^{\mathbf{1}}$ \\
\hline Age & & & \\
60-69 years old & 1.00 & - & - \\
$\geq 70$ years old & 2.83 & $1.62-4.96$ & $<0.001$ \\
\hline Family Support & & & \\
Yes & 2.87 & $1.35-6.09$ & 0.006 \\
No & 1.00 & - & - \\
\hline
\end{tabular}

$\mathrm{PR}=$ Prevalence Ratio; $\mathrm{CI}=$ Confidence Interval. ${ }^{1}$ Wald test: $\mathrm{p}$-value.

The ROC curve of the final adjustment of the Poisson model for sarcopenia reveals a significantly relevant area $($ area $=0.763 ; \mathrm{p}$-value $=0.001 ; 95 \% \mathrm{CI}=[0.629 ; 0.897])$, indicating that the model has a good predictive power. Source: Own Research.

The ROC curve of the final adjustment of the Poisson model for sarcopenia reveals a significantly relevant area (area $=$ $0.763 ; \mathrm{p}$-value $=0.001 ; 95 \% \mathrm{CI}=[0.629 ; 0.897])$, indicating that the model has a good predictive power (Figure 1).

Figure 1. ROC curve.

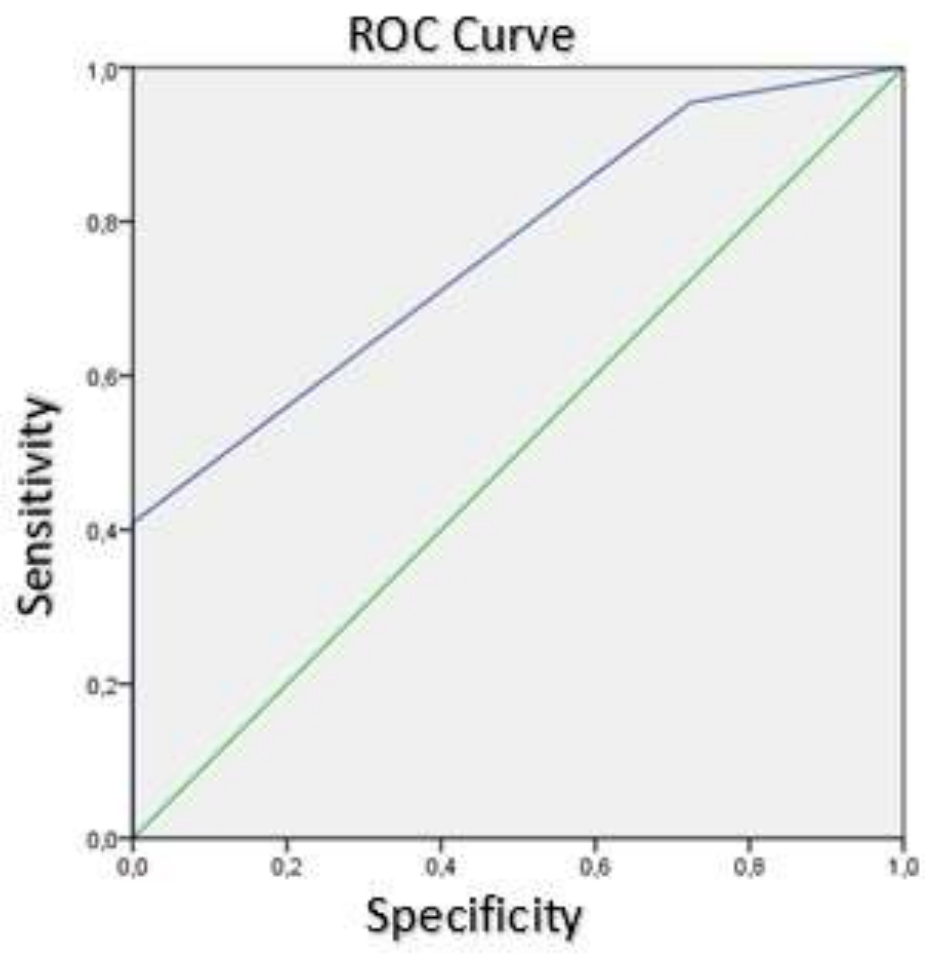

Source: Own Research.

\section{Discussion}

In this study, the prevalence and factors associated with sarcopenia and $\mathrm{SO}$ were assessed in community-dwelling older people. Among the population studied, $43 \%(95 \% \mathrm{CI}=0.295-0.567)$ were diagnosed with sarcopenia and $19.6 \%(95 \% \mathrm{CI}=$ 
0.305-0.087) with OS. These levels of prevalence are high considering previous studies (Alexandre, Duarte, Santos, \& Lebrão, 2019).

Sarcopenia and SO were identified predominantly in older males. The decrease in testosterone associated with aging contributes to the loss of muscle mass, thus, there is a marked reduction in strength and muscle mass in older males (LeBlanc et al. 2011; Hughes et al. 2001). A number of studies have reported that the prevalence of sarcopenia is higher in males, ranging from 2.5 to $28.0 \%$ (Kim et al., 2016; Yoshida et al., 2014). The loss of muscle mass and strength affect physical performance, functionality, mobility and negatively interferes with the independence of the older people. In sarcopenia, the decrease in strength occurs faster than that of muscle mass (Oliveira et al., 2011; Polyzos \& Margioris, 2018).

Differences may be observed in the prevalence of SO in the studies due to the lack of criteria adopted in the definition as well as methodological differences. Of the 51 older people assessed in the present study, 19.6\% were diagnosed with sarcopenic obesity. A study by Hwang et al. (2012) conducted in Korea, reported a prevalence for SO of $6.1 \%$ and $7.3 \%$ respectively, for males and females. Batsis et al. (2014) assessed older North Americans, with a prevalence for SO of $18.1 \%$ in females and $42.9 \%$ in males. In studies with older Brazilian females, different levels of prevalence have been reported, ranging from $21.5 \%$ to $34.2 \%$ (Santos et al., 2014; Silva et al., 2013).

Age was significant for the development of sarcopenia in older people aged $\geq 70$ years $(\mathrm{p}=0.011)$. With the progression of aging there is a loss of muscle mass and strength, this relationship is mainly explained by the gradual atrophy and loss of muscle fibers (Larsson et al., 2019). A case-control study, with older people aged $\geq 65$ years, reported that individuals aged over 85 years had a higher risk of developing sarcopenia compared to those aged under 85 years, and this risk increased in relation to older people with a lower age, aged between 65 and 74 years (Safonova \& Glazunova, 2020).

One of the conditions assessed in our study was the family arrangement, although no significance was found in the statistical tests, family support is the main social and economic support of most older people, thereby influencing the health care of this population (Hai et al., 2017). Harmonious social interaction positively affects health, thus reflecting a better quality of life for these individuals (Oliveira, Pavarini, Orlandi, \& Mendiondo, 2014; Kamen et al.2011). This family support enables a more effective routine of lifestyle habits, resulting in the encouragement of healthy eating and better metabolic control, which may be preventive factors for sarcopenia (Hai et al., 2017).

After adjusting the multivariate analysis, contributing to family support was significantly related to sarcopenia. Low income and low education have been associated with a lack of access to healthy foods, thereby leading to nutrient deficiencies, which increases nutritional risks and consequently the chance of sarcopenia (Donini et al., 2013).

Several factors interfere with dietary intake, including physiological, social and economic factors. In this age group, economic status influences the quality of the dietary pattern, resulting in inadequate nutrient intake (Buford et al., 2010). Although in our study the tests were not statistically significant, a study by Kim, Wilson, and Lee (2010) and Nicastro et al. (2011) demonstrated that nutrient intake, especially protein and essential amino acids, has an influence on muscle metabolism. Among the older people assessed, insufficient physical activity was associated with sarcopenia. Physical activity has a protective effect against reducing muscle mass and strength, corroborating the study by Murphy et al., (2014). By contrast, in China, a survey on the association of sarcopenia with lifestyle and family function, it was observed that the relationship of physical activity had no significance with sarcopenia (Hai et al., 2017). There are several causal factors for sarcopenia and SO, including physical inactivity, gender, age, inadequate nutrition and economic conditions. It should be noted that healthy eating habits and the practicing a physical activity may have a preventive effect and improve the quality of life of older people.

The study had some limitations. First, the total number of participants included in this study did not enable a relationship of the factors assessed with SO. Data collection was brought to a close with the advent of the Covid-19 pandemic. The crosssectional design is a limiting factor to determine the cause and effect relationship of factors related to sarcopenia and SO. Despite 
the limitations, the importance is highlighted of this population-based study in the field of gerontology, since it assesses a population of independent older people with similar living conditions and education.

\section{Conclusion}

The prevalence of sarcopenia and SO was high among the research participants, mostly in those aged $\geq 70$ years, and male. Increasing age was related to lower weight and reduced HGS. For sarcopenia, family support and physical inactivity were considered determining factors. Factors assessed, such as sociodemographic data, and the clinical and economic profiles were not significant for SO.

\section{Acknowledgements}

This research was financed by the Fundação de Amparo a Ciência e Tecnologia do Estado de Pernambuco (FACEPE), it was also financed by the Coordenação de Aperfeiçoamento de Pessoal de Nível Superior - Brasil (CAPES) - Fiance Code 001.

\section{References}

Alexandre, T. D. S., Duarte, Y. A. D. O., Santos, J. L. F., \& Lebrão, M. L. (2019). Prevalence and associated factors of sarcopenia, dynapenia, and sarcodynapenia in community-dwelling elderly in São Paulo- SABE Study. Revista Brasileira de Epidemiologia, 21. 10.1590/1980-549720180009.supl.2.

Batsis, J. A., Mackenzie, T. A., Barre, L. K., Lopez-Jimenez, F., \& Bartels, S. J. (2014). Sarcopenia, sarcopenic obesity and mortality in older adults: results from the National Health and Nutrition Examination Survey III. European Journal of Clinical Nutrition, 68(9), 1001-1007. 10.1038/ejcn.2014.117.

Baumgartner, R. N., Wayne, S. J., Waters, D. L., Janssen, I., Gallagher, D., \& Morley, J. E. (2004). Sarcopenic obesity predicts instrumental activities of daily living disability in the elderly. Obesity Research, 12(12), 1995-2004. 10.1038/oby.2004.250.

Beasley, J. M., Shikany, J. M., \& Thomson, C. A. (2013). The role of dietary protein intake in the prevention of sarcopenia of aging. Nutrition in Clinical Practice, 28(6), 684- 690. 10.1177/0884533613507607.

Buford, T. W., Anton, S. D., Judge, A. R., Marzetti, E., Wohlgemuth, S. E., Carter, C. S., \& Manini, T. M. (2010). Models of accelerated sarcopenia: critical pieces for solving the puzzle of age-related muscle atrophy. Ageing Research Reviews, 9(4), 369-383. 10.1016/j.arr.2010.04.004.

Carriquiry A. L. (1999). Assessing the prevalence of nutrient inadequacy. Public health nutrition, 2(1), 23-33. https://doi.org/10.1017/s1368980099000038

Choi, K. M. (2016). Sarcopenia and sarcopenic obesity. The Korean Journal of Internal Medicine, 31(6), 1054-1060. 10.3904/kjim.2016.193.

Chung, J. Y., Kang, H. T., Lee, D. C., Lee, H. R., \& Lee, Y. J. (2013). Body composition and its association with cardiometabolic risk factors in the elderly: a focus on sarcopenic obesity. Archives of Gerontology and Geriatrics, 56(1), 270-278. 10.1016/j.archger.2012.09.007.

Confortin, S. C., Ono, L. M., Barbosa, A. R., \& d’Orsi, E. (2018). Sarcopenia e sua associação com mudanças nos fatores socioeconômicos, comportamentais e de saúde: Estudo EpiFloripa Idoso. Cadernos de Saúde Pública, 34. 10.1590/0102- 311X00164917.

Cruz-Jentoft, A. J., Baeyens, J. P., Bauer, J. M., Boirie, Y., Cederholm, T., Landi, F., \& Zamboni, M. (2010). Sarcopenia: European consensus on definition and diagnosis. Report of the European Working Group on Sarcopenia in Older. Age and Ageing, 39(4), 412-423. 10.1093/ageing/afq034.

Cruz-Jentoft, A. J., Landi, F., Schneider, S. M., Zúñiga, C., Arai, H., Boirie, Y., \& Cederholm, T. (2014). Prevalence of and interventions for sarcopenia in ageing adults: a systematic review. Report of the International Sarcopenia Initiative (EWGSOP and IWGS). Age and Ageing, 43(6), 748-759. https://doi.org/10.1093/ageing/afu115.

Dent, E., Morley, J. E., Cruz-Jentoft, A. J., Arai, H., Kritchevsky, S. B., Guralnik, J., \& Vellas, B. (2018). International clinical practice guidelines for sarcopenia (ICFSR): screening, diagnosis and management. The Journal of Nutrition, Health \& Aging, 22(10), 1148-1161. 10.1007/s12603-018-1139-9.

Donini, L. M., Scardella, P., Piombo, L., Neri, B., Asprino, R., Proietti, A. R., \& Morrone, A. (2013). Malnutrition in elderly: social and economic determinants. The Journal of Nutrition, Health \& Aging, 17(1), 9-15. 10.1007/s12603-012-0374-8.

Folstein, M. F., Folstein, S. E., \& McHugh, P. R. (1975). "Mini-mental state". A practical method for grading the cognitive state of patients for the clinician. Journal of Psychiatric Research, 12(3), 189-198. https://doi.org/10.1016/0022-3956(75)90026-6.

Guenther, P. M., Kott, P. S., \& Carriquiry, A. L. (1997). Development of an approach for estimating usual nutrient intake distributions at the population level. The Journal of Nutrition, 127(6), 1106-1112. https://doi.org/10.1093/jn/127.6.1106.

Hai, S., Wang, H., Cao, L., Liu, P., Zhou, J., Yang, Y., \& Dong, B. (2017). Association between sarcopenia with lifestyle and family function among communitydwelling Chinese aged 60 years and older. BMC Geriatrics, 17(1), 1-7. 10.1186/s12877-017- 0587-0. 
Houston, D. K., Nicklas, B. J., Ding, J., Harris, T. B., Tylavsky, F. A., Newman, A. B., \& Health ABC Study. (2008). Dietary protein intake is associated with lean mass change in older, community-dwelling adults: the Health, Aging, and Body Composition (Health ABC) Study. The American Journal of Clinical Nutrition, 87(1), 150-155. 10.1093/ajcn/87.1.150.

Hughes, V. A., Frontera, W. R., Wood, M., Evans, W. J., Dallal, G. E., Roubenoff, R., \& Singh, M. A. F. (2001). Longitudinal muscle strength changes in older adults: influence of muscle mass, physical activity, and health. The Journals of Gerontology Series A: Biological Sciences and Medical Sciences, 56(5), B209B217. https://doi.org/10.1093/gerona/56.5.b209.

Hwang, B., Lim, J. Y., Lee, J., Choi, N. K., Ahn, Y. O., \& Park, B. J. (2012). Prevalence rate and associated factors of sarcopenic obesity in Korean elderly population. Journal of Korean Medical Science, 27(7), 748-755. 10.3346/jkms.2012.27.7.748.

Janssen, I. (2011). The epidemiology of sarcopenia. Clinics in Geriatric Medicine, 27(3), 355-363. 10.1016/j.cger.2011.03.004.

Janssen, I., Heymsfield, S. B., Baumgartner, R. N., \& Ross, R. (2000). Estimation of skeletal muscle mass by bioelectrical impedance analysis. Journal of Applied Physiology, 89(2), 465-471. 10.1152/jappl.2000.89.2.465.

Kamen, C., Cosgrove, V., McKellar, J., Cronkite, R., \& Moos, R. (2011). Family support and depressive symptoms: a 23-year follow-up. Journal of Clinical Psychology, 67(3), 215-223. 10.1002/jclp.20765.

Kim, H., Hirano, H., Edahiro, A., Ohara, Y., Watanabe, Y., Kojima, N., \& Shinkai, S. (2016). Sarcopenia: Prevalence and associated factors based on different suggested definitions in community-dwelling older adults. Geriatrics \& Gerontology International, 16, 110-122. 10.1111/ggi.12723.

Kim, J. S., Wilson, J. M., \& Lee, S. R. (2010). Dietary implications on mechanisms of sarcopenia: roles of protein, amino acids and antioxidants. The Journal of Nutritional Biochemistry, 21(1), 1-13. 10.1016/j.jnutbio.2009.06.014.

Kyle, U. G., Bosaeus, I., De Lorenzo, A. D., Deurenberg, P., Elia, M., Gómez, J. M., \& Pichard, C. (2004). Bioelectrical impedance analysis-part II: utilization in clinical practice. Clinical Nutrition, 23(6), 1430-1453. 10.1016/j.clnu.2004.09.012.

Larsson, L., Degens, H., Li, M., Salviati, L., Lee, Y. I., Thompson, W., Kirkland, J. L., \& Sandri, M. (2019). Sarcopenia: Aging-Related Loss of Muscle Mass and Function. Physiological Reviews, 99(1), 427-511. https://doi.org/10.1152/physrev.00061.2017.

LeBlanc, E. S., Wang, P. Y., Lee, C. G., Barrett-Connor, E., Cauley, J. A., Hoffman, A. R., \& Orwoll, E. S. (2011). Higher testosterone levels are associated with less loss of lean body mass in older men. The Journal of Clinical Endocrinology and Metabolism, 96(12), 3855-3863. https://doi.org/10.1210/jc.20110312

Lombardo, M., Boaria, A., Aulisa, G., Padua, E., Annino, G., Pratesi, A., \& Bellia, A. (2019). Sarcopenic obesity: etiology and lifestyle therapy. European Review for Medical and Pharmacological Sciences, 23(16), 7152-62. 10.26355/eurrev_201908_18761.

Mithal, A., Bonjour, J. P., Boonen, S., Burckhardt, P., Degens, H., Fuleihan, G. E. H., \& Dawson-Hughes, B. (2013). Impact of nutrition on muscle mass, strength, and performance in older adults. Osteoporosis International, 24(5), 1555-1566. 10.1007/s00198-012-2236-y.

Morley, J. E., Abbatecola, A. M., Argiles, J. M., Baracos, V., Bauer, J., Bhasin, S., \& Society on Sarcopenia, Cachexia and Wasting Disorders Trialist Workshop (2011). Sarcopenia with limited mobility: an international consensus. Journal of the American Medical Directors Association, 12(6),403-409. https://doi.org/10.1016/j.jamda.2011.04.014

Murphy, R. A., Ip, E. H., Zhang, Q., Boudreau, R. M., Cawthon, P. M., Newman, A. B., \& Health, Aging, and Body Composition Study. (2014). Transition to sarcopenia and determinants of transitions in older adults: a population-based study. Journals of Gerontology Series A: Biomedical Sciences and Medical Sciences, 69(6), 751-758. 2014;69(6):751-8. 10.1093/gerona/glt131.

Nicastro, H., Artioli, G. G., dos Santos Costa, A., Solis, M. Y., Da Luz, C. R., Blachier, F., \& Lancha, A. H. (2011). An overview of the therapeutic effects of leucine supplementation on skeletal muscle under atrophic conditions. Amino Acids, 40(2), 287- 300. 10.1007/s00726-010-0636-X.

Oliveira, R. J. D., Bottaro, M., Júnior, J. T., Farinatti, P. T. V., Bezerra, L. A., \& Lima, R. M. (2011). Identification of sarcopenic obesity in postmenopausal women: a cutoff proposal. Brazilian Journal of Medical and Biological Research, 44, 1171-1176. 10.1590/S0100-879X2011007500135.

Oliveira, S. C., Pavarini, S. C. I., Orlandi, F. D. S., \& de Mendiondo, M. S. Z. (2014). Family functionality: a study of Brazilian institutionalized elderly individuals. Archives of Gerontology and Geriatrics, 58(1), 170-176. 10.1016/j.archger.2013.07.003.

Polyzos, S. A., Margioris, A. N. (2018). Sarcopenic obesity. Hormones, 17(3), 321-331. 10.1007/s42000-018-0049-x.

Rauchbach, R., \& Wendling, N. M. (2009). Evolução da construção de um instrumento de avaliação do nível de atividade física para idosos curitibativa. FIEP Bull, 79, 543-547.

Safonova, J. A., \& Glazunova, G. M. (2020). Diagnostic Criteria and Prevalence of Sarcopenia in the Elderly. Advances in Gerontology, 10(3), $228-233$.

Santos, E. P., Gadelha, A. B., Safons, M. P., Nóbrega, O. T., Oliveira, R. J., \& Lima, R. M. (2014). Sarcopenia and sarcopenic obesity classifications and cardiometabolic risks in older women. Archives of Gerontology and Geriatrics, 59(1), 56-61. 10.1016/j.archger.2014.03.012.

Santos, V. R. D., Gomes, I. C., Bueno, D. R., Christofaro, D. G. D., Freitas, I. F., \& Gobbo, L. A. (2017). Obesity, sarcopenia, sarcopenic obesity and reduced mobility in Brazilian older people aged 80 years and over. Einstein (São Paulo), 15, 435-440. 10.1590/S1679-45082017AO4058.

Silva, A. O., Karnikowski, M. G. O., Funghetto, S. S., Stival, M. M., Lima, R. M., de Souza, J. C., \& Prestes, J. (2013). Association of body composition with sarcopenic obesity in elderly women. International Journal of General Medicine, 6, 25. 10.2147/IJGM.S36279.

Tian, S., \& Xu, Y. (2016). Association of sarcopenic obesity with the risk of all-cause mortality: a meta-analysis of prospective cohort studies. Geriatrics \& Gerontology International, 16(2), 155-166. 10.1111/ggi.12579. 
Research, Society and Development, v. 10, n. 14, e279101422205, 2021

(CC BY 4.0) | ISSN 2525-3409 | DOI: http://dx.doi.org/10.33448/rsd-v10i14.22205

Trumbo, P., Schlicker, S., Yates, A. A., \& Poos, M. (2002). Food and Nutrition Board of the Institute of Medicine, The National Academies. Dietary reference intakes for energy, carbohydrate, fiber, fat, fatty acids, cholesterol, protein and amino acids. Journal of the American Dietetic Association, 102(11), 1621-1630.

Waters, D. L., Hale, L., Grant, A. M., Herbison, P., \& Goulding, A. (2010). Osteoporosis and gait and balance disturbances in older sarcopenic obese New Zealanders. Osteoporosis International, 21(2), 351-357. 10.1007/s00198-009-0947-5.

Yoshida, D., Suzuki, T., Shimada, H., Park, H., Makizako, H., Doi, T., \& Lee, S. (2014). Using two different algorithms to determine the prevalence of sarcopenia. Geriatrics \& Gerontology International, 14, 46-51. 10.1111/ggi.12210.

Zhang, X., Xie, X., Dou, Q., Liu, C., Zhang, W., Yang, Y., \& Cheng, A. S. (2019). Association of sarcopenic obesity with the risk of all-cause mortality among adults over a broad range of different settings: a updated meta-analysis. BMC Geriatrics, 19(1), https://doi.org/10.1186/s12877-019-1195-y. 